\title{
HACIA UNA EDICIÓN CRÍTICA DE SOR JUANA
}

En 1995, para honrar a sor Juana Inés de la Cruz en el tercer centenario de su muerte, la facultad de Filosofía y Letras de la Universidad de México publicó una excelente edición facsimilar de los tres tomos que contienen el grueso de su obra. Para cada uno de ellos se eligió la respectiva primera edición: Inundación castálida, 1689; Segundo volumen, 1692; Fama y Obras pósthumas, 1700. No se trata, pues, de una edición crítica. Pero cada tomo lleva al final un cuidadoso registro de las erratas, las mejoras, las alteraciones y omisiones, en una palabra, las "variantes", insignificantes a veces, a veces muy notables, que en las sucesivas reediciones se fueron introduciendo. Este registro, al cuidado de Gabriela Eguía-Lis Ponce, es un verdadero labor amoris. Merece el agradecimiento de cuantos se interesan seriamente en la poesía y la prosa de sor Juana. El camino hacia una edición crítica ha quedado abierto.

Es verdad que la edición de Alfonso Méndez Planearte tiene algo de "crítica". El texto que en ella leemos es, en no pocos pasajes, resultado de un cotejo entre varias ediciones antiguas. Méndez Planearte procuró ofrecer una lectura sin tropiezos y sin lunares, y para ello empleó las técnicas filológicas consagradas, que refuerzan y refinan eso no técnico que es el sentido común. (Los muchos amantes de la poesía de Garcilaso la leyeron, durante varios decenios, en la edición barcelonesa de 1543, que tiene bastantes erratas. En la Canción $V$, por ejemplo, se lee que Mario Galeota huye de la palestra como si fuera "siempre ponzoñosa". Los dos grandes editores del último tercio del siglo xvi, el Brocense y Herrera, restauraron lo que evidentemente había escrito Garcilaso: no "como siempre ponzoñosa", sino "como sierpe ponzoñosa". Méndez Planearte está en la línea del Brocense y de Herrera.) 
En la Inundación castálida, fuente imprescindible para el texto de las obras de sor Juanal, hay, como es de rigor, no pocas erratas. Así, en el romance "De la más fragante rosa..." se lee (53:27) que la abeja depende íntimamente de la abeja. El disparate se corrigió en la $2^{\text {a }}$ edición: la abeja depende de la rosa. MP rechaza, por supuesto, la lección de la $I C$ e imprime: "Mas jay!, que la abeja tiene / tan íntima dependencia / con la rosa...". Pero no todas las erratas de $I C$ se corrigieron en la $2^{a}$ edición. En una de las loas dice la $I C$ que las aguas borran los prados, y las tres ediciones subsiguientes repiten el disparate, corregido por fin en la de 1709: las aguas no borran los prados, sino los bordan de flores, y es esto lo que imprime MP (377:248). En seguida me ocuparé del cotejo entre las Eds. Pero hay también erratas que persistieron en todas las Eds. hasta que vino a corregirlas MP. Así, en el Sueño (v. 492), esas partes ignorantes a las cuales se añaden las perfeccionantes, "clásica" errata de imprenta en la que nadie había reparado: ignorantes en vez de integrantes. De es. tos casos me ocuparé en las pp. 515-521.

Quienes examinen con algún detenimiento los registros de variantes que añadió Gabriela Eguía-Lis Ponce no tardarán er descubrir algo muy grave: MP da en no pocos lugares un textc distinto del de las fuentes primarias ( $I C$ y $S V$ ) cuando el de ésta: es absolutamente correcto. Es inevitable la conclusión de que en tales lugares MP le presenta al lector algo que no escribió so] Juana. No tuvo ante los ojos la $I C$, sino las reediciones de 1690: 1691 (donde, por cierto, se cambia el pomposo título Inunda ción castálida por el muy simple de Poemas); ni tampoco la pri mera edición del $S V$, sino una de las reediciones de 1693. Lc cual se debe a sus prisas, como a mí me consta. En 1949 y 1951 hablé varias veces con él en El Colegio de México, adonde ibi para hacerle consultas a Raimundo Lida. Trabajaba a marcha forzadas porque quería que el primer tomo de su edición salic ra a la luz en 1951, al cumplirse tres siglos del nacimiento d sor Juana ${ }^{2}$.

1 Emplearé en adelante estas abreviaturas: IC (Inundación castálide 1689), SV (Segundo volumen, ed. de 1692), Eds. (el conjunto de ediciones reediciones antiguas, 1689-1714) y MP (Alfonso Méndez Planearte). En lá citas de sor Juana pongo el número que MP asigna a las composiciones, sı guido del número del verso.

2 Irónicamente, en la nota 1 de la Introducción tiene que reconoce muy a su pesar, que sor Juana no nació en 1651, sino en 1648, y comen1 que ella, "mujer femenina" al fin, bien pudo quitarse tres años al decirle : 
Veamos algunos casos muy claros, comenzando con la $I C$. En ésta leemos que Carlos II tiene "visos de divino", o sea que tiene algo de Dios; en 1709 se coló una errata: "avisos de divino". || En IC se habla del costo de un trabajo; en 1709, arbitrariamente, se cambió costo por coste. || En IC se habla de la justicia de Dios, tan activa, "que ella solamente suple / cordel, verdugo y cuchillos", texto irreprochable; pero en 1709 una errata cambió ella por alli. MP reproduce estas erratas (tomadas, según parece, más de la edición de 1725 que de la de 1709$)^{3}$. Es verdad que en estos tres casos no sufre mucho el sentido, pero otras veces las buenas lecciones de IC quedaron tan deturpadas en las reediciones, que MP se vio obligado a meter mano. "Las fieras se acogen" en sus grutas, dice la $I C$; se escogen, dice 1709; se esconden, corrige MP. || En el altar de Fili "no se efunde" sangre; "no se enfunde", dice 1709; MP elimina el disparate enfunde e imprime infunde (que no deja de ser disparate). "I "Que ni aun de esa suerte / tengo por acierto / el querer que el mundo...", dice un romancillo; en 1709 el acierto se convierte en cierto, arruinando el hexasílabo, y MP remedia la falla metiendo otra sílaba: "tengo yo por cierto". || El hijo de los virreyes, recién nacido, es ya el colmo de la grandeza por ser hijo de tales padres, de manera que no debe extrañarnos la maravilla "de que lo máximo crezca"; pero en 1709 se metió una extraña errata: "de que lo mexicano crezca", con el consiguiente alargamiento del octosílabo, saneado así por MP: "de que el mexicano crezca" 4 . En todos estos casos, naturalmente, una edición crítica tendrá que regresar a las lecciones de la $I C$, auténticas y satisfactorias: visos, costo, ella, se acogen, se efunde, acierto, lo máximo.

P. Calleja que había nacido en 1651: "isi hasta santa Teresa, con ser santa, llega a restarse dos...!".

3 visos, 374:156; costo, 214:394; ella, 11:107.

${ }^{4}$ se acogen, 383:126; se efunde, 19:47; acierto, 73:62; lo máximo, 24:88. - He aquí otras "variantes" de las ediciones tardías que MP acoge por no haber visto la IC: "Tened, parad...; Dejad, esperad", caprichosamente alterado en 1709; "Tened, esperad..., Dejad, parad" (382:204 y 210). || La ciencia de fray Diego "se halla en su modo de obrar"; le halla, dice 1709, y MP lo halla (385:297). || Sor Juana reconoce que no urge que el señor arzobispo venga al convento a confirmarla, pues sabe "que ocupaciones / de negocios más precisos" reclaman su atención, versos maleados en 1709 y en MP: "qué ocupaciones / de negocios tan precisos" (11:202). || Sor Juana le presenta (le obsequia) a la virreina un dulce de nueces; representa, dicen absurdamente 1709 y MP (núm. 23, epígrafe). 
Con el $S V$, la otra gran fuente primaria, se repite la historia. MP no tuvo a la vista la edición de 1692, sino reediciones que varias veces alteran el texto. El "Pan / entre accidentes cándidos" pasa a ser "entre accidentes cándido"; || el verso "ejemplos mirando tantos" se cambia sin razón por "registrando ejemplos tantos"; |l y en el verso "la adoración, más que el contacto, llega" se cambia el orden de las palabras, de que resulta un endecasílabo pésimamente acentuado: "más que el contacto, la adoración llega" 5 . Es evidente, por lo demás, que a veces MP no manejó ni siquiera la primera reedición del $S V$, de 1693, sino las más tardías de 1704 y 1725 . He aquí un ejemplo muy claro: en $S V$ se lee: "a la fama que las cante / y al eco que las repite"; MP pone los dos verbos en indicativo (47:19), aceptando, según dice, la enmienda de Ermilo Abreu Gómez; pero ya en 1693 se lee "las canta" y "las repite".

El caso del $S V$ se complica porque cinco de las obras que contiene - los villancicos de la Concepción 1689, los de Navi. dad 1689, los de san José 1690, y la loa y el auto del Divino Narci so- se habían impreso anteriormente en la $3^{\mathrm{a}}$ edición de $I C$ (Poemas..., 1691). Por lo visto, sor Juana mandó esas cincc obras para una edición "aumentada" del tomo primero, y si st reimprimieron en el $S V$ fue para que los poseedores de la $I C$ o de su $2^{a}$ edición (1690) no se quedaran sin ellas. Pero el textc de 1691 -que por razones cronológicas sería la editio princep ("pre-edición" más bien) de las cinco piezas- tiene abundante: errores, corregidos en 1692 en ese $S V$ no manejado por MP. Si guen algunos ejemplos:

Los villancicos de la Concepción 1689 se escribieron para l: catedral de Puebla de los Ángeles. En uno de ellos, que empie za "Siendo de Ángeles la Puebla...", escribe sor Juana: "Dizqu" los doctos de allá [de Puebla] / Claridad de Dios os llaman /

5 cándidos, 354:10; “ejemplos mirando...", 7:34; "la adoración...' 65:12. - Sin embargo, la edición de 1693 mejora a veces el texto de $169^{c}$ En 1692 leemos que María sube las gradas del templo, porque "levita Amor / la grave porción en ella" (tal como un mago levita a una persona vista del público); pero faltaba mucho para que existiera el verbo levitar; trata de una simple errata, corregida en 1693: no levita, sino le quita a Mari la "grave porción". MP mantiene la errata levita (357:10). I| Otro caso: en ‘ $S V$ dice sor Juana que las Musas están muy remisas, "sin que haya quien d limosna / una que ahora me dicte"; esta mala sintaxis se enmienda en 169 . "sin que halle, ni aun de limosna, / una que..." (MP: "sin que haya, ni au de limosna...", 48:3). 
de Ángeles", texto muy bien enderezado en 1692: "la Ciudad de Dios... y de Ángeles". || En los villancicos de Navidad 1689 se lee que los cabellos ensortijados del Niño Jesús son anillos hechos "para prendas amantes", errata corregida en 1692: anillos (ganchos) "para prender amantes". || En uno de los villancicos de san José, tres personajes le preguntan a otro: "Pues digo, ¿qué oficio fue / el que tiene san José?"; el sentido pide "Pues diga [usted]", que esijustamente como se enmienda en 1692. En los tres $\operatorname{casos}^{6}$ el texto que da MP es el defectuoso.

También el texto del Divino Narciso debiera tener como base el $S V$, no la "pre-edición" de 1691 (y mucho menos las reediciones de 1709 y 1725 que MP maneja). La beldad de Narciso es "sin igual peregrina", dice la "pre-edición", verso cojo bien corregido en $S V$, "sin igual y peregrina", y mal corregido en 1709, "sin igualdad peregrina". || En 1691 se lee que las aguas que están sobre el cielo (cf. Génesis, 1:6-8) forman un yelo; en $S V$ se enmienda: "forman cristalino velo" . || La Gracia es guardiana de la Fuente "desde que ayer empezó / su corriente", errata corregida en $S V$ "desde que a ser empezó". || En el mismo parlamento, la Gracia está esperando que Narciso llegue, se asome a la Fuente y "de ti se enamore", lección que $S V$ corrige: "de si se enamore". || En 1691 se lee que las piedras se rompen el ceño al morir el Divino Narciso, y en $S V$ se corrige: se rompen el seno ${ }^{8}$. En un par de casos, la coincidencia entre la "pre-edición" y el SV es fuerte argumento contra las alteraciones tardías hechas en el Divino Narciso. Seguramente es de sor Juana el cultismo natante, cambiado por nadante en 1709. || En

6 Claridad > la Ciudad, 282:74; prendas > prender, 288:42; diga > digo, 299:146.

${ }^{7}$ Según nota de MP, en cierta edición suelta y moderna (México, 1924) del Divino Narciso se lee velo por "errata"; él dice que mantiene lo que se lee "en todos los textos", o sea yelo, y que se limita a modernizar la palabra. Pero, curiosamente, lo que dice su texto no es hielo, sino velo. (O sea que MP atinó con la lección verdadera ipor casualidad!)

8 peregrina $>$ y peregrina, v. 11; yelo $>$ velo, 174; ayer $>$ a ser, 1155 ; de $t i>$ de $s i$, 1167; ceño > seno, 1719. (Cosa notable: la errata ceño por seno se repite en el Epinicio al conde de Galve, cuyo texto procede de un volumen colectivo impreso por Sigüenza y Góngora en 1691; y es sorprendente que MP no la corrija, estando, como está, en rima con trueno: 215:32.) Cf. también "busco a mi Dueño amado, / ignoro dónde [se esconde]" > "y ignoro dónde". - En la loa del Divino Narciso hay casos análogos: "Y tú, esposo, y tus vasallos" > "y vos, vasallos", v. 174; confirmar "en beneficios" > "con beneficios", 279. Cf. también 134-135, 215, 340 y 474. 
1691 y 1692 se lee: "los ojos, por quien asoma / el alma, en sı resplandor / muestran, con luces de sol, / benignidad de paloma”. En 1709, en cambio: “...entre su arrebol / muestran, con lu. ces de sol"9.

Cuestión aparte es la de los villancicos de la Concepciór 1676. MP, que se basa en la edición suelta de México 1676, sє tomó esta vez el trabajo de consultar el $S V$. (dándole el epítetc de "rarísimo"); aquí se omiten seis de los ocho villancicos, he cho verdaderamente inexplicable. No puede ser que el editor sevillano -don Juan de Orúe, rendido admirador de sor Jua na-haya decidido seleccionar sólo los dos villancicos centrale: (e imprimirlos como "letras sagradas" sueltas). Lo que pudier: ser es que los tres primeros y los tres últimos villancicos no fue ron enviados a Sevilla por haberse traspapelado los folios ini ciales y finales de la edición suelta. Sea como fuere, el texto dr esos dos villancicos tiene en el $S V$ varias enmiendas que segura mente son de sor Juana (y que MP registra en las notas).

La edición suelta de los villancicos de san Pedro Nolasc (México, 1677) tiene en el ejemplar manejado por MP una nc ta "autógrafa" de sor Juana que dice que los dos últimos villan cicos (los de la misa) "no son míos". Según eso, al enviarle $\epsilon$ impreso a Orúe se olvidó sor Juana de suprimirlos, de maner: que apócrifamente aparecen en el $S V$.

Los villancicos de santa Catarina, impresos en Puebla es 1691, pasaron también al $S V$, pero no en 1692 sino en la reed ción barcelonesa de 1693, donde se imprimieron con alguna enmiendas debidas seguramente a la mano de sor Juana (y qu MP no registra) ${ }^{10}$.

${ }^{9}$ natante $>$ nadante, v. 481; resplandor $>$ arrebol, 1363. Esta segunda alter ción se hizo seguramente para salvar la rima en -ol; pero sor Juana bien $\mathrm{p}$ do rimar por "equivalencia acústica". Y, además, el arrebol no les queda bie a los ojos.

10 Por ejemplo: "en vez de topar muerte" (v. 48) > "en vez de encontr muerte", 1693; || "ya que la más peregrina" (v. 77) > "Yo, que la más peregı na..." (o sea: 'Pues yo digo que...'); en el v. 67, en vez de a sí, lo que dir 1693 es assí, como es lógico; y la copla debe terminar en suspensivos, igu que las tres precedentes. - GEORGINA SABAT DE RIvERs demuestra en NRFH, $c$ (1974), 391-401, que en 1693 se imprimieron en Barcelona tres reedicion. del SV; pero, ajuzgar por los cotejos que ella hace, las discrepancias son $\mathbf{n}$ nimas: diferentes grafías, como deste y de este, tyrano y tirano, y erratas obvic como cierra por tierra, dexarè por dexarà. (La única mejora que encuentro el rótulo dèzimas cambiado por el más correcto de quintillas: edición de $\mathrm{M}$ núm. 153.) Aquí considero esas tres reediciones como una sola. 
Por otra parte, en esa reedición de Barcelona 1693 no faltan errores y cambios caprichosos, que MP adopta (cito primero el texto de $S V y$ en seguida el de 1693): "malograrás ofendiendo / lo que no alcanzaste amando" > "malograrás ofendido" (lo cual arruina no sólo el paralelismo, sino el sentido); || "siendo todo mi poder / el tener fijeza en nada" > "el tener firmeza en nada" (cambio totalmente gratuito); || Atenas desterró a Aristides, "que, aun en lo bueno, es delito / el que se singularicen" > "se singularice" (pero sor Juana lo dice de todos los que se singularizan, no sólo de Aristides) "1" || "No es la malla y el escudo / seña de valor subido" > "delvalor subido"; || el águila se sostiene en un pie "y en otro guarda cálculo pequeño" > "el cálculo pequeño"; || el estómago es "centrifica oficina" > "científica oficina" (lo cual es disparate: el estómago es la "centrífica oficina", el taller central distribuidor de la sustancia que allí se extrae de los alimentos) ${ }^{12}$.

Algo parecido ocurre al comienzo del romance-dedicatoria, donde sor Juana le presenta sus versos al lector: "ni disculpártelos quiero / ni quiero recomendarlos" (tomo 1, edición de 1690), estropeado en la reedición de 1691: "ni disputártelos", que es lo que imprime MP.

He aquí una serie de pasajes de la $I C$ que han sufrido alteraciones en la edición de MP:

Sor Juana, que ha estado a las puertas de la muerte-como ella dice, exagerando tal vez- a causa de un tabardillo, le dice al arzobispo fray Payo que su enfermedad fue un aviso de Dios: "del violento ardiente azote / alzó piadoso el castigo, / que movió como recuerdo / y conozco beneficio". Sólo mozió el azote, pero no me dio, como imprime MP (11:143).

Los celos, dice la mundana monja en un aplaudido romance, son inseparables del amor; todo amante vive con ellos; quien se desinteresa de lo que siente y hace la persona amada da muestras de tibieza en el amor; y quien se cree seguro de ser siempre amado da muestras de "villana confianza"; "la confianza ha de ser / con proporcionado medio: / que deje de ser mo-

11 Cf. la Respuesta a sor Filotea, líneas 533 ss.: "Aquella ley políticamente bárbara de Atenas, por la cual salía desterrado de su república el que se señalaba en prendas y virtudes...".

12 ofendido, 7:103; firmeza, 380:105; singularice, 48:120; "del valor", 89:38; "del reloj", 216:215; "el cálculo", 216:135; científíca, 216:235. 
destia / sin pasar a ser despego": modestia es el agachar la cabeza, el sufrir en silencio; hay que buscar un sano equilibrio entre el amor y los celos. La "corrección" de MP, molestia en vez de modestia (3:207), estropea el sentido ${ }^{13}$.

Menciona sor Juana a "aquellos que / sutilmente defendie ron / que de la nube los ampos / se visten de color negro", $\epsilon$ sea que sostuvieron que las nubes son blancas, y que cuando la: vemos negras es sólo que "se visten" de un ropaje negro. Nadic defendió que la nieve se viste de negro, que es lo que imprim MP (3:267).

"No es amor correspondencia; / causas tiene superiores, , que las concilian los astros / o la engendran perfecciones" e un texto clarísimo: las se refiere a causas, y la a correspondencia La enmienda de MP, "lo concilian..., lo engendran" (4:119) ni tiene razón de ser.

Sor Juana imagina ya al bebé de los virreyes "pasarse por 1 : cartilla / hasta que un Catón parezca”. Esto se deja entende bien: el niño va a ser inteligentísimo y aprenderá a leer en ul santiamén. La lección pastarse (24:63), introducida en 1709, $\epsilon$ absurda. (Si hubiera necesidad de corrección, podría ser pe searse, ;pero no pastarse!)

"Esperaba la guadaña, / todo temor los sentidos, / todo cor fusión el alma, / todo inquietud el jüicio". MP corrige: "todos tr mor", "toda confusión" (11:57 ss.). La construcción es rar: pero seguramente la repetición de todo está hecha adrede.

"Para que... todo lo atiendan, / ¡vengan, vengan!". MP cr rrige: "lo atiendas" (385:131); pero esas palabras no se dirigen fray Diego, sino a sus cuatro relevantes prendas.

"Alza $t u$ alma dichosa el presto vuelo". MP: "Alza tú, alma c chosa" (188:9); pero sor Juana se dirige a Laura, no a su aln (alza no es imperativo, sino $3^{\text {a }}$ persona de indicativo).

"Pues no soy la primera / que, con hurtos de sol y primav ra, / echan con mil primores / una mujer en infusión de flore y "sacan una belleza destilada". Es una concordancia ad sensu Se entiende: "Antes de mí ha habido infinitos poetas q1 echan... y sacan..."; MP corrige: "la primera / que echa..

${ }^{13}$ Lo notable es que MP, de manera excepcionalísima, adoptó en es caso la "corrección" de Ermilo Abreu Gómez, tan apaleado por él (y no s razón) en numerosos lugares. (Tampoco se acepta la actitud de "modest en el soneto núm. 176, "que da medio para amar sin mucha pena": "Si e es fuerza querernos, haya modo...: / no se hable más en celo ni en sos| cha, / y quien da la mitad, no quiera el todo".) 
(214:25). pero se abstiene de cambiar sacan por saca (se arruinaría el endecasílabo).

"Yo, que soy Amor, y efecto / que de su belleza nace...". La "corrección" de MP no tiene sentido: "de que su belleza nace" (383:391). El amor es efecto de la belleza del virreinal bebé (que cumple un año), no efecto del cual nace esa belleza.

En la misma loa, la edición de 1725 , base del texto de MP, tiene, por errata, punto y coma en vez de signo de interrogación en el verso "[ $[$ ] en qué consiste su esencia?", que sin ella se vuelve ininteligible; para poner algún remedio, MP altera la sintaxis y suprime el que del verso siguiente (383:254).

En cambio, la pregunta "mas ¿qué voz...", como dicen las Eds., se convierte en un aseverativo "más que vos" (375:480), a pesar de que la pregunta se gemina en el v. 481: “Qué festivas voces...?”.

"Pues dejando de excepción, / que..." tiene sentido: basta ponerle coma a dejando; está mal corregir "dejando la excepción" (378:103).

"Un Sexto Aurelio, un Propercio". MP suprime el segundo un y convierte a los dos escritores en uno solo, "Sexto Aurelio Propercio" (38:163); pero éste se llamaba Sexto Propercio, no Sexto Aurelio Propercio.

En la loa núm. 379 hay que trastrocar las acotaciones Presente y Pasado que pone MP en los vv. 436 y 440 . Lo que pasa es que las Eds. omitieron en el v. 436 la acotación Pasado ${ }^{14}$.

Sigue ahora una serie de pasajes del $S V$ alterados también indebidamente en la edición de MP:

"Concuerdas palabras, / acciones contextas". El sentido de contextar es claro: 'cotejar', 'comparar o contrastar una cosa con otra'. Está mal la corrección "acciones contestas" $(70: 56)^{15}$.

${ }^{14}$ Otras malas correcciones: asegurarse $>$ asegurarme, 3:105; exempciones (o sea 'exenciones') > excepciones, 13:23 (en 36:50 sí transcribe bien MP: exempta> exenta); "un amar" > "un amor", 16, epígrafe; "besapiés y besaboca" > besapiés y besabocas", 31:60 (el pequeño José tiene dos pies y una boca); "pero $m e$ han de ayudar todos" > "pero que han", 274:71; "alija la carga" > "alija, carga", 263:3; "influyendo con" > "influyendo en", 374:73; "en el griego" > "en lo griego", $381: 52$ ("el griego" es 'la lengua griega'); "voz amorosa" > "voz armoniosa", 382:58 (corrección caprichosa, que además destruye el paralelismo con el "amante cuidado" del v. 63).

${ }^{15}$ En Los empeños de una casa, acto I, v. 387, menciona Leonor a "muchos / que, de mi fama incitados, / contextar con mi persona / intentaban mis aplausos" (querían constar si se justificaba la fama). También Alberto G. Salceda, editor del tomo 4, imprime aquí contestar. 
"Las acciones midamos / de la pasada edad, y a la futura / primicias le dará $a$ la conjetura". Obviamente sobra una $a$; MP suprime la primera (372:95), pero lo que pide el sentido es quitar la segunda: de "la pasada edad" (Adán, Abraham, Jacob) va sacando Lucero sus "conjeturas" en cuanto a "la futura" (la redimida por Cristo).

"[El día de cumpleaños] acuerda / círculos que ha cumplido de luces, / cláusulas que han cerrado de estrellas". Así dicen las Eds., obvia errata. MP uniforma: "han cumplido", "han cerrado" (62:3), pero mal: es el día el que " $h a$ cumplido" y " $h c$ cerrado".

"Y así, aunque los que intenta son retornos, / las que ejecuti sólo son ofensas". La construcción es algo rara (cf. supra, "tode temor..., todo confusión"), pero se entiende. MP corrige "lo qut intenta" (65:43) iy deja "las que ejecuta"!

"al contrario voraz, necio la expuso" > "necia lo expuso" (216:249). Según la nota, ésta fue la lección que prefirió MI después de rechazar necio lo y necia la; pero el "necio la expuso' de las Eds. no está mal: el manjar es necio por interponerse en tre el calor natural y el húmedo radical, y "la expuso" se relierı a la sustancia.

"De la deidad se admire el beneficio / y no se corresponde" dicen las Eds., donde el sentido pide "se admira... y no s corresponde". La corrección de MP, "se admite" (63:45) no pí rece buena.

A sor Juana le han pedido que glose una quintilla que ct mienza con el verso "La acción religiosa de", y ella, además d declararla inglosable, desafía a glosar lo siguiente: “...el qu aquesta quintí-/ lla hizo y quedó tan ufá-, / no, pues tiene ta buena ma- / no, glose esta redondí-". MP cree que nos hall: mos ante "un mero percance de imprenta" (;de todas las Eds.! e imprime "...el que aquesta quintilla / hizo...", etc. (144) ${ }^{16}$.

La Virgen María le tiene tanto amor a san Bernardo, "qr con su sangre le cría". MP, a pesar de que recuerda en la nota " tradición de que la Virgen llegó a regalar [al santo] con la c leste dulzura de sus pechos", vela púdicamente el le cria y, sin menor explicación, pone "que su sangre le daría" (334:34) ${ }^{17}$.

16 Lo curioso es que más tarde sí glosó sor Juana la endiablada quintil La glosa, hecha en toda forma, pondera lo difícil que ha sido componer Se conserva en el "manuscrito Moñino", del cual hablaré infra, p. 522.

17 Otros casos: "a su beldad y primor" > "a $t u$ beldad", 384:429 (el ado dor de la condesa de Galve entrega el alma a subeldad); "dísticos no de e 
Abundan en la edición de MP los cambios gratuitos, innecesarios, sin base en las Eds.

He aquí cinco de las alteraciones de este tipo que hay en una sola pieza, la Loa a los años de fray Diego Velázquez de la Cadena (núm. 385). La Naturaleza hace, "atenta, / el que las especies vivan": es un $e l$ sustantivador; no hace falta corregir: "atenta a que..." (v. 21). || Prosigue la Naturaleza: "¿qué dificultad hay / para que, a querer la mesma / obra que hago en una especie, / en un individuo hiciera?": a querer: 'si yo quisiera'; MP imprime "para creer que la mesma" (v. 36). || "VVengan todas las prendas / para hacer un compuesto de todas ellas!": MP cambia: "un compendio" (v. 158; cf. v. 200, donde conserva el compuesto). || Habla la Naturaleza: "quiero / que volváis a repetir, / como en anuales obsequios, / lo que para hacerle entonces, / ahora para recuerdos". La idea es clara: "al hacer a fray Diego le di cuatro prendas sobresalientes; hoy es su cumpleaños, buena ocasión para recordarlo'. MP omite el comoy dice: “...repetir / en anüales obsequios / lo que para hacerlo entonces..." (vv. 206-207). I| "Segunda A traigo yo, en que / el Agrado se demuestra". Sor Juana es aficionada al artificio de los octosílabos agudos terminados en partículas átonas. Así en el romance-prólogo: "pues al cabo harás lo que / se te pusiere en los cascos; / y adiós, que esto no es más de / darte una muestra del paño". Hay que poner en esas partículas una especie de acento: "harás lo què", "no es más dè". Lo mismo en la Loa: "en que / el Agrado se demuestra". MP reacomoda caprichosamente los dos versos (316-317): "Segunda A traigo yo, / en que el agrado se muestra".

Un recorrido por los demás textos nos hace descubrir gran número de estos cambios, debidos seguramente al constante empeño de MP de hacer lo más fluida posible la lectura de sor Juana.

"...dulces y alegres cuando Dios quería, / pues ya no os puede usar la musa mía" > "...cuando Dios quería, / ya no las puede usar..." (214:58); || “...que es, en mis amantes voces, / una cosa la que entiende..." > "que en estas amantes voces / una cosa es la que..." (368:153-154); || "y el que fin fue del círculo

gantes poemas" > "dísticos no, elegantes poemas", 62:10 (corrección gratuita); "nos precisa el tiempo" > "nos precisa el riesgo", 370:1446 (mal). - Añado, en apéndice, dos falsas correcciones de textos procedentes de la Fama y Obras pósthumas (1700): borbollones cambiado por el más neutral borbotones, 49 bis: 23; "no soy yo lo que pensáis" > "la que pensáis", 51:13. 
primero / principio dé feliz al que sucede" > "y que el fin: (193:7); || me di (imperativo) > dime (368:1074; pero en e v. 1099 sí respeta MP el me $d a)$; || "la presteza; y así,.." > "l: presteza. Así.." (385:165); || "llegue a lograr, y así es bien, que..." > "llegue a lograr. Asi es bien..." (368:451); || "Ya, si l: brarme confío..." > "Y asílibrarme confío" (99:15); || "Ya a tu plantas..." > "A tus plantas" (381:141);

"Dicha y desdicha de entrambos [Fabio y Silvio] / la suer les descompone" > las suertes (4:62); || "puntos tan graves / com el de la religión" > punto tan grave (370:616; explica MP que c lo del v. 627 se refiere a punto, en singular; su enmienda es ocic sa, pues el verso 617 dice "el de la religión"); || "Vuelto en lám na el papel, / en bronce se ha convertido" > en bronces (49 bi 122); || llama > llamas (380:221; pero es la misma llama del 196); || la cuenta $>$ las cuentas (11:122); || diferencias $>$ diferenc (374:288); || tálamos > tálamo (216:721); || "fueron tipos sólo" "tipos solos" (216:401);

capillo > capullo (377:153; pero también existe capillo); || "c haberlo vencido" > "de verlo vencido" (311:63; parece lectu descuidada de averlo); || "No temas, Joven" > "No temas, Jaco (372:1342; resulta raro, en efecto, ese Joven, pero es difícil q1 sea errata de imprenta); || archero $>$ arquero (75:6); || avenenac $>$ envenenados (114:7); || un barbado $>$ un bárbaro (241:43, jus ficado así: bárbaro 'que ignora el latín'; pero el ignorante es estudiantón, no el señor a quien él se dirige); || engazan > eng. zan (370:332); || engrandece > agrandece [!] (202:14); || espacio: espacio (11:62; pero ya espacio significa 'despacio'); || mandato mandados (11:208); || rigoroso > riguroso $(91: 49,216: 307$ y 309:c en cambio, MP deja intacto el calorosos de 216:375); $\|$ ' disforme simio" > "el disforme "jimio" (38:22); || "iVálgate Dio > ¡Válgame Dios!" (303:24);

"las arrianas dogmas" > "los arrianos dogmas" (370:517) y" tas [enigmas]" > estos (372:1183; son sustantivos que a causa la terminación - $a$ solían hacerse femeninos: en el Sueño, v. 8 MP respeta las fantasmas); también las centinelas $>$ los centine (368:847); por otra parte, MP convierte injustificadamente ، en loca (91:25) y penoso en penosa (165:4), y, en cambio, favon $d a>$ favorecido (39, epígrafe), también sin razón;

"Esos versos, lector mío" > Estos (1:1; pero sor Juana dice 1 porque ella está en México y sus versos ya en Madrid); || “ ¿ $C$ es eso?" > “Qué es esto?" (375:233); || "ese obsequio" > "este ol quio" (18:27); || "ese recelo" > "este recelo" (214:193); || "d 
que éste no es cuidado" > "que esto" (3:141); || "Déjense de aqueso" > "de aquello" (375:295);

"¿quién pensara / que un pobre romance mío... / mereciera aquella ofensa...?" > merecía (38:5); II "probar... / por qué el uno ha de llorar, / por qué el otro ha de reír" > "por qué, el uno, han de llorar; / por qué, el otro, han de reír" (344:7-8, enmienda forzadísima, e inútil además); || "Una $E$ y una $L$ me $h a$ cabido" (concordancia con el sujeto más próximo) > "me han cabido" (384:365); || "no quede rio ni fuente" > "no queden" (377:245); || "han mostrado"> "se han mostrado" (50:80; el han es raro, pero el se han no remedia gran cosa); || "caber no puede" > "no pudo" (308:6); || compone > componen (380:266); || se antepone > se anteponen (381:196); || "Miren qué tiene que ver / años con sofisterías!" > "qué tienen" (375:285); || "y Jericó me dio el texto" > "me $d a$ " (290:63); || "dar tránsito" > "da tránsito" (372:281; no hace falta: el infinitivo depende de para, v. 279); || "el cielo os dé" > "os da" (374:238);

"que ir la reina hermosa" > "que el ir" (272:27; pero el hiato antes de $i r$ no tiene nada de extraño); || "un querer pagar" > "el querer pagar" (46:151); || "que diese, como sol, / la vuelta al mundo" > "como el sol" (187:14); || "[que Dios os aumente la edad] como la merecéis vos" > "como lo merecéis vos" (123:3);

"cuanto menos se conoce, / es más nocivo el estrago" > "cuando menos se conoce" (2.91); || "que cuanto los favores son más grandes, / tanto menos obligan a la deuda" > "que cuando los favores" (65:37); || "alguna vez / de cuantas hacéis cautivos" $>$ "de tantas que" (125:20);

"...guarismo. / Pues aun antes que nacierais..." > "Pues aunque antes..." (49 bis:9; el aun está bien; lo que está mal es el punto; hay que leer "...guarismo, pues aun antes...”); || "celebrar de Carlos / años" > " $a$ Carlos" (377:490); || "de reloj humano / vital volante" > "del reloj" (216:205); || "de cuanto el Betis baña" > "en cuanto" (370:1726); || "de su progenie" > "en su progenie" (372:1542; aquí de significa 'por', 'a causa de'); || los ojos de Matilde son acreedores "de las más doradas flechas" de Cupido > " $a$ las más" (36:68); || "Daros las pascuas, señora, / es en mí gusto y es deuda" > "es mi gusto y es mi deuda" (33:2); || "será cometer un robo / por hacer una lisonja" > "para hacer" (31:20); || "con brújula" > "por brújula" (379:245); || "lo primero con que encuentro / es un seis, que no es más de uno" > "y lo primero que encuentro / es un seis, que no es más que uno" (266:10, corrección del todo gratuita); 
"no se hable más en celo ni en sospecha" > " $y$ en sospecha" (176:11); || "las que a Venus mullidas plumas, / espumas, / os da el mar" > "plumas / y espumas" (374:275); || "sus ojos el agua / y el barro mi ser" > "el barro" (284:11); || "copiar las flores a Mayo" > "al Mayo" (39:179); || "su boca" > "la boca" (214:205); || "tengo yo de los ratones / el convento todo limpio" > "tengo ya" (11:10); || "viendo que ya voces daba" > "que yo" (372:437); || "ya os asesto el memorial" > "yo os asesto" (11:31); || ello > ella (372:236); || la alma > el alma (18:30); || "d€ suceder en el cetro" > "de sucederle" (370:279).

Merece una consideración el uso de los pronombres $l e, l a$ ) lo en el español de sor Juana. Pedro Henríquez Ureña (citadc por MP en nota a 4:107) afirma que ella distinguía entre el $l$ acusativo y el le dativo, "como se ha hecho siempre en América' (en el español americano no prosperaron ni el leísmo ni el laís mo), y que los casos de le acusativo y la dativo que hay en si obra "se deben a los impresores europeos". Siguiendo este "cri terio" (que es también el de Rufino José Cuervo), MP anunci: que corregirá el leísmo y el laísmo de las Eds. Pero él mismo re conoce que hay casos, como oirle, recibirle y enhebrarle, asegura dos por la rima (puestos tal vez, dice, porque a sor Juana así "sı lo rogó el consonante"). Hay que observar, por un lado, que lo "impresores europeos" no siempre usan el le acusativo (cf., el dos versos consecutivos, 46:77-78, "le aplauden" y "celebrar $l o$ " Por otra parte, a veces (cf. 21:132-137 y 167; 70:66 y 71) olvid MP su propósito y deja el le (corrige "lo intitulé Caracol", per" deja "os le remito", "procuraré enmendarle", "le llevan", etc.) Los casos de laísmo, como "aunque cualquiera la salga, / la hé brá de salir cual quiera" (36:60) y "por que tu pie la sirva de cc rona" (382:77) se corrigen siempre.

A propósito de "que cuanto añado al discurso / tanto usurpo a los años" (2:144) dice MP que "la sintaxis regular pr diría les" (usurparles), pero que él lo deja tal cual, primero, po que el verso se echaría a perder si lo retocara, y segund porque los casos de le por les no son raros en el siglo de oro ${ }^{1}$ razones más que suficientes para respetar ese $l e$, especie de pa tícula invariable. El resultado es que MP corrige a veces ("qu no ha de darle [> darles] tu vista / a mis pesares aliento", 6:6:

\footnotetext{
${ }^{18}$ Cita aquí algunos de los ejemplos recogidos por Cuervo en sus $A p u$ taciones críticas: "y débale a mis números el mundo" (Góngora), "pena q1 justamente le es debida / a sus continuos y nefandos vicios" (Cervantes), el
} 
"que mejor acuerdo / a mis consejos le [>les] debas", 376:253) y a veces no: deja "le sirven" y "le sujete" (62:53 y 70) donde "la sintaxis" pediría les. Y, extrañamente, imprime "que le deis a vuestros padres / la felicidad de veros" (25:141) donde las Eds. dicen "que les deis". (Muy probablemente ese le es una de las erratas modernas de que hablaré en la p. 514.)

En resumen, creo que así como en una edición crítica debe respetarse - salvo erratas evidentes- el texto de las fuentes primarias (imprimiendo costo y no coste, rigoroso y no riguroso, centrífica y no científica), así también hay que dejar tal cual la vacilación de $l e, l o$, la, que refleja la realidad de la lengua a fines del siglo xvir. Supone Henríquez Ureña que ya entonces había un "español americano" con sus diferencias respecto del "español europeo". Pero, aun suponiendo eso, hay que tener en cuenta que sor Juana estuvo en contacto con gran número de españoles, comenzando con los virreyes, y sobre todo con muchos libros españoles. Muy bien puede ser que haya escrito cosas como "le intitulé Caracol" y "que tu pie la sirva de corona", aunque al hablar dijera "lo intitulé" y "le sirva de corona".

Parecido al caso de los pronombres de tercera persona es el de la preposición a para indicar objeto directo. La ausencia y la presencia de esta $a$ está ejemplificada en los primeros decenios del siglo Xvi por Garcilaso, que dice "el caro hermano buscas" (Elegía I, v. 40) y por Juan de Valdés, según el cual hay que decir "el varón prudente ama a lajjusticia", pues de otra manera lo que podría entenderse es que lajusticia ama a ese varón. El español "normal" acabó por apartarse de uno y otro uso: por lo general, se dice o se omite la preposición según que el objeto directo sea persona o cosa: "Veo a Juan" y "Veo el libro", "Busco al hermano" y "Amo lajusticia". Pero la vacilación ha sido muy persistente 19 . Son frecuentes casos como el de "contestar [o responder] la pregunta", pero también "a la pregunta", "resistir la tentación", pero también "a la tentación"20. En los textos impresos de sor Juana es muy visible la vacilación:

19 Rafael LAPESA, Historia de la lengua española, \$97.6, registra omisiones "anormales" en Lope ("no disgustemos mi abuela") y en Quevedo ("acusaron los escribas y fariseos la mujer adúltera").

${ }^{20}$ Entre los escritores actuales no hay, según creo, ninguno que emplee la a "anormal" tan abundantemente como Octavio PAz. Cito, con número de página, su Sor Juana Inés de la Cruz (1982): desdeñar a los juegos de palabras (83), describir a la literatura del siglo XVII (84), visitar al convento (175), admirar a esos objetos (321), citar a todos los libros que tenía (325), 
por una parte, presencia de $a$ (eliminada por MP): "suspender al juicio" (39:207), "celebrar al natalicio" (46:78), "turbar $a$ los ojos" (369:181), "esperar alclarín" (381:101), "como a mancebo, querido; / como a antiguo, respetado" (378:197-198), "aun almenor descuido no perdona" (216:142)21;

por otra parte, ausencia de $a$, remediada - a veces sin ninguna razón- por MP: "alumbrar el mundo" (377:12), "asombrar el mundo" (157:8), "dominar el mundo" (378:356), "consumir [el fuego] la sangre" (370:1413), "convertir un apóstol" (55:7), "despreciar el amante" (4:123), "parar" y "suspender el viento" (377:60 y 62), "ver ese dios" (367:378), "violentar el sacrificio" (89:83), "que mi fineza / ayude su aclamación" (382:32), "escucharéis... el idioma claro" (378:18) ${ }^{22}$, "El que..., / El que... / llegad a adorar" > "Al que..., Al que..." (372:802 y 806), " $E_{\text {. }}$ que... / todos los bienes le sobran" > "Alque..." (239:31; perc está en serie con otros seis "Elque...").

Ahora bien, hay casos en que la falta de la preposición a pudierc explicarse porque el impresor la dejó "embebida" en una a inme diatamente anterior o posterior, por ejemplo "que hay a quien lt pese" (33:7, o sea "que haya a quien le pese"); "de quien apren

agrupar a los poemas según sus asuntos (367), abandonar a los modelo (399), contemplar a su propia imagen (466), el rigor con que trataba $a \mathbf{s}$ cuerpo (530), castigaba a su cuerpo $(531,587)$, cultivar a la poesía (549) amar $a$ las ideas (589). Los casos son incontables. Supongo que Paz decí normalmente "cultivar la poesía", y que la a es una especie de manierisme practicado sin mucha coherencia, pues son frecuentes las intromisiones de uso "normal": dice "La vida no explica la obra y la obra tampoco explica $a$, vida" (13), "amamos el cuerpo de una persona pero también a su almz (248), "los grupos que componían a la sociedad" (34) y "los elementos qu componen la sociedad" (199), "el soneto acompaña a otros poemas" (34؟ y "canciones para acompañar unos bailes" (404). Pero también dice "hos rar un virrey" (209), cuando lo que se dice en español "normal" es "honr: a un virrey".

21 Este perdonar a es muy de Góngora: cf: mis "Notas al Primero sueñ NRFH, 43 (1995), p. 386, nota al v. 142. - Al hijo de los virreyes le dice s Juana que ya ha experimentado "florida a la primavera, / al estío macilent / con su sazón al otoño / y con su escarcha el invierno" (25:101-104). I siento que el cuarto verso debe leerse "y con su escarcha al invierno" (c rrección de una sola errata), mientras que $\mathrm{MP}$, al suprimir la preposició corrige los otros tres.

${ }^{22}$ MP corrige: "al idioma claro". Pero el texto de las Eds. es irreprocl ble: "escucharéis... / el idioma claro..., / el desvelo que costó asistirlo, / estudio que costó adornarlo". 
der / pudiera hacer..." (46:22, o sea " $a$ hacer"); "el alma... / y $a$ la edad rompiendo / los fueros..." (377:512: "ya a la edad"; pero MP, quizá por descuido, suprime el ya); "una razón de belleza, / belleza de la razón" (379:352, enmendado por MP: "y úna [del verbo unir], a razón de belleza, / belleza de la razón"). Así también "a la que... / o aquella que..." (40:45: " $a$ aquella que"); "pues aquel que inmortal era, / el amor hizo mortal" (368:1588: " $a$ aquel"); "atender aquella circunstancia" (372:178: "a aquella"); "a éste, aquél" (378:122: "a éste, $a$ aquél").

Retoques como éstos, parte de la modernización que normalmente se hace en las más exigentes ediciones de clásicos, son sin duda una gran ayuda para la lectura. Está bien imprimir mostrasteis y no mostrastis ${ }^{23}$, habery no aver, tirano y no tyrano, teatro y no theatro, etc., y no sirve mucho el mantener proprio, assumpto, fragrante y reduzgo. Desde luego, hay que dejar mesmo, conceto, perfeto, etc. cuando están en rima, y quizá no haya que modernizar la palabra antojos (cf. 216:440), palabra normal antes de que se impusiera anteojos ${ }^{24}$. En cuanto a las intervenciones de MP en los versos portugueses del núm. 249 y en los "negrillos" de los núms. 224, 258 y 274, me parecen superfluas: es obvio que sor Juana no dominaba el portugués, y la estilizada habla de los negros no estaba rígidamente establecida.

En varios casos las enmiendas de MP hacen ciertamente más claro el texto, pero en realidad son innecesarias. Dicen las Eds.: "es imposible saberlo, / luego también es decirse", lectura tolerable; no hace falta corregir "luego también lo es decirse" (30:39); || "si mi entendimiento... / tan incapaz de conocerse fuera" > "de conocerte" (182:6; pero conocerse pudiera estar bien); || "los que... están ocupados" > "las que... ocupadas" (375:490; el propio MP reconoce que el masculino puede pasar); || "cuyo pelo airoso / desprende sutil... / banderas de Ofir" > que prende (271:18; pero desprende es defendible); II "al modo que aquellos que..." > "de aquellos que" (3:265; podrá ser cacofónico el queque-que, pero la expresión es gramaticalmente correcta); \#

23 Predominan los pretéritos normales en -steis, pero también hay nacistis (28:3), mostrastis (243:20), quisistis (378:174), confesastis, hicistis y servistis $(247: 13,18,49,57)$.

${ }^{24}$ MP "moderniza" también dos veces (39:111 y 377:52) la palabra rariedades, aplicada las dos veces a la delgadez del aire. Pertenece al vocabulario de Góngora (romance "Ciego que apuntas...": "Una torre fabriqué / del viento en la raridad"). No creo que sor Juana haya escrito rariedades; lo extraño es que la errata exista dos veces en la $I C$. 
“...unión sería. ¡Oh, aunque tan repetida...!" > "aunque repetida" (216:699: la supresión de tan aligera el endecasílabo, pero la enmienda no se impone); || "en quien iguala" > "en quien st iguala" (381:445 y 448; pero el se no es muy necesario); || "cuyos ajos..., cuyo estudio / bebe de la teología" > beben (12:19; pero e] verbo puede concordar con el sujeto más próximo); $\|$ "y advierta... / que no le escribo más este soneto / que porque todc poeta aquí se roza" > "que le escribo, no más, este soneto / por. que todo poeta aquí se roza" (158:13-14: dos cambios para co. rregirle a sor Juana la sinéresis de poeta [cuasi pueta], que no es rara en el siglo XVII); || la Encarnación de Cristo "los Misterio: eslabona, / y es, para nuestro remedio, / del de la Redenciór medio / y el de la Creación corona". > "y es... / del de la Reden ción, medio; / del de la Creación, corona" (358:12; pero la co rrección no hace falta: el misterio de la Encarnación es, por una parte, el medio para realizar el de la Redención y, por otrá parte, viene a coronar o perfeccionar el misterio de la Crea ción; no hay por qué convertir en sustantivo el verbo corona); | "ya te esperan sus abrazos" > "ya te espera con sus brazos" (370:590 es verdad, como observa MP, que el los del v. 592 no puede re ferirse sino a brazos, pero los brazos están ya implicados en lo: abrazos); || "a que una guerra se trate" > se trabe (370:596; pero s trate puede estar significando 'se llegue a emprender'); || "dı Adán tu padre y de Isaac" > "de Abraham tu padre" (372:245; e lo que se esperaría, en efecto; pero bien puede entenderse "Yc soy el Dios de Adán [padre de todos los mortales] y de Isaa [padre tuyo]": Abraham no es padre, sino abuelo de Jacob); | "si una aprehensión las quita" > "y si una aprensión" (372:529 pero bien puede medirse a-pre-hen-sión [cf. Sueño, v. 769: cor pre-hen-der]; además, el hiato entre si y una es muy normal); | "háganle salva" > "hágale salva" (380:91; se refiere al singular fu go, pero es un fuego plural, "con sus luces, / sus centellas llamas"); || "que vean / la hermosa luz que $a$ un tiempo conce diste" > "que vean / hermosa luz que un tiempo concediste (189:4; está muy bien suprimir la preposición a, pero hay qu conservar el artículo la); || "Y no hallándose..." > "Y no ha hall dose" (372:650: heroico esfuerzo de MP por remediar la sinti xis; lo que pasa es que a la oración de gerundio siguen otra incidentales y, francamente, el hilo se le va a sor Juana. Es 1 que sucede en un intrincado pasaje del Sueño, vv. 151 ss.).

Correcciones indubitables son las que se hacen por razó: del sentido (cf. "siempre venenosa" > "sierpe venenosa"). Tan 
bién cuentan las razones de métrica. Una sílaba de más o de menos (un simple $y$, un la) estropean el verso, y urge restaurarlo. Hay un villancico (núm. 263) hecho en coplas que terminan en endecasílabos como "el rostro, el corazón, el alma, el pecho" y "los luceros, el sol, luna y estrellas"; con toda razón imprime MP "los ríos, los arroyos, fuentes, mares" al final de una copla donde las Eds. dicen "ríos, arroyos, fuentes, mares" (verso hipométrico); con razón imprime sustentan en vez de sustentaron (372:1666) y esta en vez de aquesta (350:29). Pero a veces no hay razón suficiente. No hace falta decir "que Carlos nace" (376:132) en vez de "en que Carlos nace"; basta leer "Y así el día dichoso en / que Carlos nace" para que conste la seguidilla. El verso "Édipo en enigmas tu ingenio" está bien si se hace hiato entre Édipo y en; no se impone la corrección "Édipo en los enigmas" (62:25). Cuatro versos de una loa (378, entre los vv. 280 y 300 ) están retocados para que sean dodecasílabos perfectos; pero son versos "calderonianos" de arte mayor, basados en el ritmo más que en el número de sílabas. El cambio jácara > jacaranda (222:7) es completamente injustificado, pues se trata de un estribillo de versificación irregular.

La repetición de la palabra-rima olvidarte en el soneto de consonantes forzados núm. 180, wv. 2 y 7 , es clara errata de las Eds.; MP, atendiendo al soneto paralelo (núm. 181), pone bien agraviarte en vez del olvidarte del v. 7. (Y es raro que no haya hecho otro tanto en el núm. 182, donde mantiene la repetición de la palabra-rima pudiera: el cotejo con el soneto 181 bis hace ver que en el v. 2 hay que leer quisiera en vez de pudiera.) En el soneto "En perseguirme, mundo, ¿qué interesas?" (núm. 146), que no es de consonantes forzados, las Eds. presentan dos de esas repeticiones: entendimiento (w. 3 y 7 ) y riquezas (w. 5 y 8); en el v. 7 MP pone pensamiento en vez de entendimiento (pero mantiene las dos riquezas). De hecho, no es imposible que las repeticiones se deban a sor Juana, que en este caso habrá violado muy adrede las reglas sonetiles ${ }^{25}$. Tal vez pasa lo mismo en una redondilla cuyos versos 2 y 3 terminan en hacer, pero la corrección de MP, hacer > a ser (372:224), deja bastante borroso el sentido. La corrección "así intento" > "así quiero" (372:22) es equivocada: es verdad que el v. 22 repite el intento que ya estaba

${ }^{25}$ Es lo que, con buenos argumentos, sostiene Gabriela Eguía-Lis en su tesis inédita. Curiosamente, en el ms. Moñino (cf. infra, p. 522) se lee grandezas en el v. 5, pero se mantiene la repetición de entendimiento. 
en el 20, pero en un caso es sustantivo y en el otro es verbo (artificio de parole identiche). La repetición de tener en 370:1264 y 1266 es más trivial, pues se trata de un romance (MP cambia un tener en obtener .

También las razones de simetría son poderosas. En sus autos y en sus loas es sor Juana imitadora entusiasta de las simetrías calderonianas: paralelismos, correspondencias, repeticiones (generalmente a cargo de la Música) de estribillos o cuartetas líricas que interrumpen de trecho en trecho el discurso. Si en la primera sección de una loa se repite una y otra vez el estribillo " $(\mathbf{Y})$ en pompa festiva / celebrad al gran dios de las semillas", justo es enmendar dos casos aislados de "con pompa festiva" (367:88 y 182), lo mismo que los dos casos anómalos y aislados de "plantas y flores" en vez de "fuentes y flores" (368: 9 y 158). Si MP imprime "Yo salgo" (37:1787) en vez de "Ya salgo" es porque el Ya está en desarmonía con los tres Yo que siguen. Dicen las Eds.: "o José miente, o se engaña, / pues ignora o sabe que..."; pero a "o miente $o$ se engaña" correspondería un "c ignora $o$ sabe", que es como imprime MP (372:1057). Si en la serie "Yo la $A$ ", "Yo la $D$ ", "Yo la $N$ ", etc., aparece un "Yo $E$ ", jus. to es corregir: "Yo la E" (385:312); y si las prendas de fray Diegc se enumeran sin artículo, justo es quitarlo en "la Nobleza' (385:475). Es justo añadir, a veces, un estribillo faltante (368:166; $370: 993$ y 1008; 383:175-176). También es defendibl la supresión del estribillo en 372, a continuación de los vv. $145^{2}$ y 1463 (por simetría con los otros parlamentos); pero la adi ción del estribillo en 383:377 y el cambio vivan > vivid er 379:448 son menos convincentes ${ }^{26}$.

Intercalo aquí una digresión sobre tres cuestiones ecdóticas he terogéneas:

1) Es casi seguro que ciertos errores en los nombres propio (sobre todo de la tradición clásica) se deben a sor Juana y no los impresores. Quien se salvó de ahogarse gracias a un delfí: ("escamado combés") no fue Anfión, sino Arión, como explic MP (nota a 26:39), aunque no corrige el lapsus. (Arión aparee en 197:4 y en varios pasajes del Neptuno alegórico.) Lo que :

${ }^{26}$ Hay algún caso parecido en otras composiciones: "con la razón lo q1 alcanzo, / y con fe lo que no entiendo" > "con la razón lo que alcanzo; / a la fe lo que no entiendo" (106:30); "si en el cálculo no engaña / y se yerra $\epsilon$ el guarismo" > "no engaña / y no yerra..." (50:184). 
cambia MP es Thetis por Telus en varios lugares de una loa (núm. 383), porque Thetis no es diosa de la tierra; pero a MP se le escapa Thetis en las acotaciones de los vv. 150, 152 y 161. (En otra loa, 380:129, Thetis sí es diosa marina.) En el Sueño, v. 627, MP cambia Themis por Thetis, tal vez sin razón. El cambio Almone $>$ Alcione se explica porque MP no pudo identificar a la rara Almone; y el llamar Titán a Titón (Titono), el marido de la Aurora, era confusión frecuente ${ }^{27}$. Dirigiéndose a José, el hijito de los virreyes, sor Juana se refiere a la madre llamándola "la Leda de tal Apolo, / de tal Cupido la Venus" (25:147), craso error, muy probablemente de imprenta, pues Leda, la del Cisne, es personaje archiconocido; la madre de Apolo es Latona (mencionada así varias veces en el Neptuno); por necesidad métrica, sor Juana podrá haber empleado eruditamente el nombre griego de la diosa, Leto, y la confusión de Leto con Leda no es muy de extrañar. Otro caso parecido: menciona sor Juana los dolores que "sintió en el leño encendido / de Egea el amante tierno / por la venganza del tío" (20:19), "alusión mitológica que hasta ahora se nos escapa, o acaso un lapsus cuya corrección tampoco alcanzamos" (MP); en efecto, es obviamente un lapsus del impresor: Egea en vez de Auge, amante de Hércules (cf. Ovidio, Heroida IX, 49; el "tío" es Euristeo). Theudio en vez de Theudis (370:1029) debe de ser errata de las Eds., pues el P. Mariana, fuente única de las noticias de sor Juana sobre los visigodos, dice Theudis. Los cambios Wandalia > Vandalia y Walia > Valia (370:453 y 989) obedecen al programa de modernización, pero yo siento que sería justo conservar la $W_{s}$ en homenaje a los viejos impresores que emplearon esa letra de insigne rareza. El cambio Veragua > Veraguas (191:2) no se justifica; las dos formas están documentadas (y en el epígrafe mantiene MP el Veraguas). Hay, finalmente, el insoluble problema del Ara si es del SV (Ara si-es en 1693, Arasies en 1715), que MP, se diría que provisionalmente, convierte en Araxes (48 bis:68).

2) Sor Juana es aficionada a ciertos arcaísmos o vulgarismos ya "estilizados" en la lengua literaria. En la Carta al P. Núnez dice, por ejemplo, norabuena y aina. Estas voces suelen acentuar

27 Para Themis, Almoney Titán, cf. mis citadas "Notas al Primero sueño", sobre los w. 93, 627 y 898. Tampoco se justifica el cambio Pigmaleón > Pigmalión (103:39): cf. el soneto de Francisco de Figueroa: "Con triste llanto y tierno sentimiento / ablandó Pigmaleón la piedra dura...", y el soneto "A Pigmaleón" de Gabriel Fernández de Rozas, Noche de invierno, Madrid, 1662, f. 3. 
el tono ligero y humorístico de ciertos versos: "hacia donde non debiera", "aunque non debiera", par Dios (antecedente de pardiez), "[estoy] de dome a Dios", en buen hora, "estuve un tris de...", "no está un dedo de...", "hételo Guevara", "cuando hétele que sale", "están diciendo coméme", "desmayos / que os tengo referido". MP moderniza todo esto: "no debiera", por Dios, "de doyme a Dios", en buena hora, "en un tris", "a un dedo", "hételo a Guevara", "hétela que sale" (la Virgen), comedme, "os tengo referi$d o s$ "; no respeta sino vuesarced y gavilane, y eso porque la modernización dañaría al metro ${ }^{28}$.

3) La edición de MP abunda en erratas (modernas) de imprenta. Una de ellas está, por así decir, bien "documentada". MP, que no sólo respeta las pintorescas peculiaridades de una composición escrita en "sayagués", con su tamañito, su polido y su pescudar, sino que explica en nota esas peculiaridades, una de ellas el rústico hue (por fue), debe de haber deplorado el fue que se puso en el texto (362:22). Es una de las muchas erratas que afean los textos de sor Juana (y los del propio MP en sus introducciones y sus notas $)^{29}$. Algunas son intrascendentes: lector convertido en tector (16, epígrafe), gócesle convertido en gocésle (24:17), y dijole en dijóle (285:56), "vuestro ojos" (124:14), "Oh dulce luces" (214:56), acostubrados (368:1804), etermos (381:495); pero muchas son serias, y aun graves: haber convertido en hablar (6:57), la fama > la cama [!] (43:105), enfenice > efenice (49:115), "en mis afectos" > "es mis afectos" (91:61), viviendo > girando [!] (124:12), santo > tanto (137:21), "en qué te ofende" > "en qué ofende" (156:3), maltratado > maltrado (214:60), "no haya miedo que..." > "no hay miedo" (214:111), fui > fue (214:325), mote > monte (222:18), "que de minimus" > "de que de minimos" (246:4), "Contra una tierna rosa / mil cierzos se conjuran" > "un tierna rosa / mil cierzos conjuran" (316:16-17), descollaste > descollante (321:14), "a todos os ato" > "a todos ato" (374:88), en el todo > en todo (378:9), se admiran > se miran (379:437), pudieran $>$ pudieron (382:16), sirva > sirve (382:77), principe > principio $(383: 27)$, me

28 "non debiera", 33:28 y 88:28; par Dios, 49:105 y 299:18; "de dome a Dios", 14:72; en buen hora, 323:15 y 371:26; un tris, 214:236; un dedo, 48:55; hé telo, 38:213 y 311:112; coméme, 43:76; "tengo referido", 11:164; vuesarced. 158:12; gavilane, 49:20.

29 En los colofones se lee: "La edición estuvo a cargo de Alfonso Mén. dez Planearte y Alí Chumacero", pero creo que la culpa recae más en Chu macero que en MP, ocupado, más que en otra cosa, en la preparación de los originales. 
trae $>$ me atrae (383:415). Falta el v. 13 ("Vengan a verio todos") en el núm. 302; en el núm. 385, a continuación del v. 144, falta asimismo el verso "de que ha de fabricarse mejor cadena"; en el núm. 346 están invertidos los vv. 16-17, y en el núm. 375 falta la acotación "Lealtad" antes del v. 261.

Sor Juana se merece una edición no menos cuidadosa que las que Robert Jammes y Antonio Carreira nos han dado de Góngora. La de MP, según lo que acaba de verse, dista de esa meta, pero es un avance muy considerable. La distancia entre ella y la de su predecesor Ermilo Abreu Gómez es enormemente mayor que la que falta recorrer para llegar a la edición cien por ciento fidedigna. Abreu Gómez no tenía, desde luego, una formación humanística como la de MP, y no estaba familiarizado con la poesía del siglo de oro ni con sutilezas teológicas y filosóficas. MP leyó despacio a sor Juana, siguiendo el hilo del discurso poético, tan sutil a veces, escudriñando la sintaxis, no siempre muy lineal que digamos. Y el resultado es que halló un prodigioso número de gazapos ocultos hasta ese momento en la maleza de las Eds. Podemos imaginárnoslo en el momento en que prepara para la imprenta la ensalada de los villancicos de la Asunción 1690 y llega a estas dos seguidillas, dichas por sendos interlocutores (311:13-20):

$$
\begin{aligned}
& \text {-El aceite a mí juzgo } \\
& \text { que me compete, } \\
& \text { que es mi voz clara y blanda } \\
& \text { como el aceite. } \\
& \text {-No negarán los niños } \\
& \text { que aceite atizan, } \\
& \text { porque traen de ordinario } \\
& \text { sus lamparillas. }
\end{aligned}
$$

Aquí se detiene. Relee. Medita. ¿Por qué los niños no negarán (o sea: aceptarán) la claridad y blandura de esa voz? Y de pronto ve lo que sucede: jese No es errata por Lo! Los niños -monaguillos, pienso yo- que despabilan las lámparas traen siempre manchas de aceite en la ropa (lamparilla es 'lámpara', pero también 'lamparón'); el aceite, pues, no es siempre claro y blando. (En resumidas cuentas, el segundo interlocutor contradice chistosamente al otro: " $\mathrm{N}$ No nos presumas de tu buena voz!'). El Lo convertido en $N o$ es una vulgar errata de imprenta, debida seguramente a que el v. 9 dice también "No negará" (pe- 
ro aquí sí está bien el $N o$ ). La restauración $N o>$ Lo es una minucia, pero de ella depende nada menos que el sentido. Estas minucias (tremendous trifles, como intituló Chesterton un libro de ensayos breves) abundan en la edición de MP. Ya mencioné el cambio "y una razón de belleza" > "y úna, a razón de belleza..." (no sólo adición de la preposición $a$, "embebida" en la $a \mathrm{~d} \epsilon$ "una", sino un acertado acento diacrítico en úna). Y hay que añadir que muy a menudo - como en el caso de $N o>$ Lo- ni si quiera explica MP que ha hecho un cambio.

"Otra vez vuelve el Pan a dar honores / a mis tristes temores" dice Lucero en El cetro de José (372:272). Esto no puede ser. ¿Po qué las menciones (proféticas) del Pan (eucarístico) habían d darle honores a Lucero, que representa al Demonio? Todo lo cor trario: le dan horrores, que es como acertadamente corrige MP.

$\mathrm{Al}$ final del romance "Finjamos que soy feliz" (núm. 2) d cen las Eds.: "Aprendamos a ignorar, / pensamientos...". MF que ha seguido paso a paso las laberínticas confidencias qu desde el comienzo le está haciendo sor Juana a su Pensamient ("triste Pensamiento", v. 2), no necesita cavilar mucho para ve que esos pensamientos del final son errata: se trata del mism Pensamiento del comienzo.

"Si es causa Amor productivo / de diversidad de efectos... comienza otro romance (núm. 3). Tal como se lee en las Eds el productivo es un pleonasmo: bastaba decir "Si amor es cau: de efectos diversos". Pero obviamente es una errata de impre ta, y MP tiene razón al imprimir "Si es causa Amor produc va...", con un hipérbaton parecido al de "Si al imán de t1 gracias atractivo...", 165:5.

Varios personajes alegóricos hablan acerca del Rey ( edad, su deidad, etc.), y uno de ellos dice (377:552 ss.):

\footnotetext{
Y tu soberana consorte, en quien deben carmín los jazmines, candor los laureles.
}

$$
\begin{aligned}
& \quad \text { Y su soberana } \\
& \text { consorte, en quien beben } \\
& \text { carmín los jazmines, } \\
& \text { candor los claveles. }
\end{aligned}
$$

(He puesto a la izquierda el texto de $I C$ y a la derecha el MP.) Ya el impresor de 1709 había corregido la errata deben, ] ro MP corrige las otra dos, haciendo, ahora sí, diáfano el sex do. (A propósito de los jazmines rojos y los claveles blan recuerda MP la "púrpura nevada" y la "nieve roja" de las m llas de Galatea.) 
El reino de la Nueva España, dice sor Juana en su romanceepístola a Diego Valverde, anda malo "para África", pues no tiene ninguna novedad que ofrecer. ¿África? No, sino Ática (39:151), como cumplidamente explica MP en la nota respectiva ${ }^{30}$.

He aquí otra minucia: "que infama el hierro al escorpión herido" > "que infama al hierro el escorpión herido" (171:3). Y otra: "saluda / como suele $e l$ sol al alba" > "como suele al sol $e l$ alba" (371:4): es el alba, a punto de disiparse, quien saluda al sol que llega (así la Ley Natural saluda "al nuevo Sol de la Fe"). Y otra más: "que parezca... / el bastón, cayado humilde, / y el bastón cayado regio" > "y el cayado, bastón regio" (374:321).

Hay correcciones más radicales. He aquí una: "cantando aquellas anàdes / que nunca pasan de tres"; pero el cantar (popularísimo, cuasi-proverbial) ${ }^{31}$ no dice anàdes, palabra inexistente, sino "Tres ánades, madre, / pasan por aquí: / mal penan a mí", y por eso MP imprime "cantando aquellas Tres ánades" (26:43). Y otra: dice sor Juana que el atrevimiento de un pincel (que quiso, eu vano, retratar la belleza de la virreina) le da alientos para acometer esa misma empresa, no con pincel, sino con palabras: "que tan gloriosa desgracia / más causa corrió que miedo". Así dicen las Eds. Pero correr causa no tiene sentido. Después de vacilar entre "más causa brío" y "más causa gozo", MP se decidió por "más causa ánimo que miedo" (19:4); y hubiera podido confirmarlo con la reflexión del Sueño, w. 781810, sobre el atrevimiento de Faetonte: terminó en fracaso, sí, pero en vez de causar terror, "alas engendra a repetido vuelo / del ánimo ambicioso".

Presento ahora un rápido desfile de "minucias" en que MP da señales de su sagacidad.

Composiciones de arte menor: "se extienda al común provecho" > "se extienda el común provecho" (3:336); || "si el res-

${ }^{30} \mathrm{MP}$, que no vio la $I C$, atribuye la lección África a Abreu Gómez, y dice que corrige la errata de 1725, Átrica. Pero Átrica está ya en la edición de 1690 (que tampoco vio MP). Seguramente el corrector de 1690 quiso convertir Africa en Ática, pero omitió tachar la $r$. - Es curioso el caso del soneto núm. 183, que comienza así en la $I C$ : "Probable opinión es que, conservarse / la forma celestial en su fijeza, / no es porque en la materia hay más noble$z a . . . "$. Pero ocurre que también el v. 6 termina con nobleza. El impresor de 1709 , por lo visto, quiso cambiar la nobleza del v. 3 por firmeza (que queda muy bien); pero la corrección fue a dar al v. 2, desbancando a fijeza (que estaba bien); y además, la repetición de nobleza quedó tal cual. Para remediar esto, MP "aprovechó" la corrección firmeza y la puso en su lugar.

31 Cf. Margit Frenk, Corpus de la antigua lírica popular, núm. 182A. 
tituirse no puede" > "si él resistirse no puede" (4:105); || se distin. guen $>$ se distingue (4:133); || "No hagas que un amor dichoso / se vuelva en afecto triste" > "en efecto" (5:58); || "...y Láquesis, a] formarlos, / de un solo copo los hile" > "al formarlas..., las hile" (6:67: se refiere a "nuestras dos vidas"); || "Hoy, contra el order del tiempo, / se tienen por bien empleados / privilegios de pre sentes / los años que ya pasaron" > tienen, sin el impersonal $s$ (13:14: contra la ley del tiempo, los años pasados tienen privile gios de presentes); || la voz, "al tiempo que es preferida..." > pre ferida (21:78); || "se corta / a aquel cuello" > "a aquél el cuello (31:39); || "al oriente" > "el oriente" (31:54); || "libre parece qu nacen / sus hijos" > libres (37:90); || cuántos > a cuántos (37:97), || ellos > ellas (38:123: las pandectas); || "cuando más alto, / tant más lejos" > "cuanto más alto" (39:23); || pintores > pintar (43:71); || "no sabéis quién sois" > "quién soy" (44:65); || Palisc $>$ Palicos (46:58, discretísima restauración); || "impedida el alier to" > impelido (47:21); || bergante > bergantes (49:190: los menci nados en las cuartetas que anteceden); $\|$ tubernaria $>$ tabernar (50:119); || disparas > disparan (61:15); $\|$ método > métodos $(62: 2$ en serie con cátedras, y en razón del metro); $\|$ excuso $>$ excu (62:59; sujeto, el Amor); || "a italiana" > "a la italiana" (67:9; c mo en seguida "a la española"); || "de tus bellos ojos" > "de $s$ bellos ojos" (70:63, sagaz enmienda); || "en lugar de dar / co fites al gusto, / dentera les das" > "le das" (72:4); || "pone tú hiel" > ponle (72:47); || flexible> fluxible (74:66); || "el incendio" "al incendio" (75:10); || tomo > toma (84:68); || "si aborrezec quien me quiere, / ¿qué haré con quien aborrezco?" > "c quien me aborrece" (85:24; las Eds. nunca corrigieron la ob' errata: la asonancia es é-e); || "no sube puntos" > "no sabe punt (87:43); || "tu amor" > "su amor" (102:6); || "tuvo ser" > " $t$ ser" (102:19); || imposible> impasible (103:79); || prensas > pren. (104:52); || avista > a Vesta (111:15, espléndida corrección) alegría > alegoría (123, epígrafe); I| "de vergel" > "del verg (129:2); || "Rosa que... / ostentas" > "te ostentas" (135:2).

Composiciones en metro italiano: "el fuego... hace hui sangre" > "hace hervir" (177:7); || "la sacia" > "lo sacia" (183:€ saciado es el apetito); || "cuando a su recio natalicio ofrece / telarverde palma victoriosa" > "a su regio natalicio ofrece / th verde, palma victoriosa" (209:3-4; pero bien hubiera pod quedar "tutelar, verde, palma victoriosa"); || son iguales > iguales (213:45); || "alegaba la concha [contra las perlas] / si ellos dientes son, ella es la boca" > "si ellas" (214:70); || 
le queda en fuga" > "en zaga" (214:341); || "máximas, negras, longos entonando" > longas (216:58); || "para que... hicieron" > hicieran (216:536); || renovar > remover (216:794); || formada, convertida, ayudada > formadas, convertidas, ayudadas (216:870 ss.: "las fantasmas"); || desamparado > desamparada (216:964).

Villancicos: no espere $>$ no esperes (217:38); || "de las estrellas y el yelmo" > "de las estrellas el yelmo" (222:14); || hermosura > hermosa (257:6); || "no tuvo para su alteza" > "no tuvo para él alteza" (261:13); || "podemos serlo" > "podemos sólo" (261:39); \| "tus penas... / oigan tus querellas" > "oigan, $y$ tus querellas" (263:29); || "con santo desinterés..., que..." > "con tanto desinterés" (240:44); || templando > temblando (249:75); || sube > suba (273:44); || "siendo mares de llanto" > "siendo, en mares de llanto..." (284:42); || cuanto > cuando (332:24).

Auto del Divino Narciso: "y es natural que lo teman" > "que la teman" (v. 300: se refiere a "mi ciencia"); || efecto > afecto (316); || misteriosas > misteriosa (588: se refiere a "petición"); || "Pues tan conformes estáis / en la elevada eminencia" > " $y$ en la elevada eminencia" (672: así se endereza la sintaxis); || "con todo el curso luciente" > "en todo el curso luciente" (1331).

Auto de El mártir del Sacramento: "ayáis librando" > "vayáis librando" (v. 21); || "que oigáis" > "que me oigáis" (195); || impresos > impresas (221: "las especies"); || "que él ha seguido"> "que lo ha seguido" (1166).

Loa de El cetro de José: "le abraza" > "la abraza" (v. 44; se refiere a "la parte"); || "no tanto" > "no es tanto" (257); || sacrificarlas $>$ sacrificarla (298: "la ofrenda").

Auto de El cetro de José: "si las desvanece un sueño" > "si los desvanece" (v. 526; se refiere a los "timbres y blasones"); || severas > severos (544); || "su intención" > "tu intención" (787, muy sagaz corrección); || "y quien habla" > "quien habla" (1054); || "el que teme / mi Soberbia, el que del mundo / el daño antiguo remedie" > "teme / mi Soberbia que del mundo..." (1391; la supresión de el aclara la sintaxis: 'aquel de quien mi Soberbia teme que remedie la culpa de Adán').

Loa de la Concepción: "Ya que ecos repetidos / salieron de nuestros pechos / rayos de amor..." > "Ya que, en ecos repetidos, / salieron..." (v. 279).

Loa del Rey, I: concepto > concento (v. 59); || "al viento" > "el viento" (353: es el sujeto de "entregó"); || "elados leños" > "alados leños” (363; o sea 'navíos').

Loa del Rey, II: caricia > codicia (v. 46; o sea 'enorme de- 
seo'); || "fatiga $e l$ hambre" > "fatiga del hambre" (129); || me pidas > me digas (190); || "Luego no eres tu esencia?" > "luego no eres tú su esencia", sin interrogación (217); || "Yo soy" > "Y yo soy" (316).

Loa del Rey, III: corrija, repita > corrige, repite (vv. 46 y 48; el subjuntivo estorba al sentido); || "se llama suyo" > "lo llama suyo" (67: el Sol llama "suyo" al Día); || "las dificultan" > "la difi. cultan" (152).

Loa del Rey, IV: "el Sol" > "del Sol" (v. 396: el reflejo se for ma de los rayos del Sol); || "y que a sus influjos" > "ya que a su: influjos" (450).

Loa del Rey, V: "comunicar el poder" > "comunicará el poder (v. 205).

Loa de la Reina: alcanza > alcance (v. 21: en serie con $\epsilon$ "pueda" del v. 18); || "te la doy" > "te lo doy" (113: el consent miento); || "empiece la Memoria" > "empiécela la Memoria" (149. || flexible > fluxible (156); || "le puede"> "se puede" (232); || "qu su imperio" > "que en su imperio" (339); || "y pues es vencimieı to" > "y pues elvencimiento" (348).

Loa de la Reina Madre: "Bella deidad, que las señas..." "que en las señas..." (v. 25).

Loa del Virrey: "que sus perfecciones" > "que en sus perfe ciones" (v. 20); || ocupan > ocupen (131); || gozosa > gozosas (14 las ninfas).

Loa de la Virreina (Loa en las huertas): quieres > quiere (v. 14 el sujeto es "el atrevimiento"); || conceptos > concentos (201; se $\epsilon$ rresponde con la "armonía" del v. 200).

Loa del Primogénito: "con sólo un Sol abrasaba" > se abra $b a$ (v. 3: en correspondencia con se abrasa, v. 4); || "Sin dude que nuevo errado Faetonte, / el carro del Sol de España": así lee en la $I C$ (oración incompleta); las reediciones ponen a en vez de carro (y vuelven a dejar incompleta la oración); I corrige acertadamente: "que a nuevo errado Faetonte / el $c c$ $d a$ el Sol de España" (144-145); || "sí puede ser" > "no puc ser" (361); || acaricien..., vivifican > acarician..., vivifiquen $(4 \mathrm{C}$ 406); || "no puede ser" > "sí puede ser" (443).

Loa de la Condesa de Galve: "animoso me expongo" > an $s a$ (v. 50; en efecto, habla la Música); || "mido el tiempo y la mido: / aquél breve y espacioso; / aquésta, intensa o remis: "aquél, breve o espacioso" (70); || "armónicamente suenar como la de los martillos / tan repetida experiencia" > "com la de los martillos" (215). 
Loa de fray Diego Velázquez de la Cadena: "Por mí, adornados de escamas, / y por mí, armados de testas, / los peces el mar habitan, / moran el monte las fieras" > "armadas las testas" (v. 44: los peces, adornados de escamas, viven en el mar; las fieras, con sus testas armadas [de cuernos, de colmillos], viven en el monte); || "servirle no rehúsa" > "servirte no rehúsa" (153: se le está hablando a la Naturaleza); || "Y los dos Diegos", "Y aqueste noble auditorio" > "Y a los dos Diegos", "Y a aqueste" (421 y 437).

Finalmente, es de elogiar la atención que MP concede a las acotaciones de las loas. Según parece, sor Juana se limitó a indicar el nombre (o la inicial) del personaje que habla, y las acotaciones fueron puestas por los impresores españoles. Pero a veces faltan y a veces están equivocadas. Faltan, por ejemplo, varias indicaciones de Aparte, tan útiles para la comprensión del texto. MP tuvo que enderezar no pocos entuertos. Por ejemplo: en la loa de la Reina, no Entendimiento, sino Voluntad (v. 181), no Memoria, sino Música (213 y 220), y el Tiempo sale, no "con una brújula y un tintero", sino, como se ve por su parlamento, "con un espejo" (239); en la loa del Virrey, no Belona, sino Venus (249) y no Venus, sino Belona (261 y 324); en la de la Virreina, no Vertumno, sino Pomona (181), no Vertumno, sino Flora (187), no Céfiro, sino Flora (196 y 202), y no Pomona, sino Flora (316); y en la del Primogénito, no Sol, sino Venus (325).

Hasta aquí he estado comentando, en cierto orden, las "variantes", que registra Gabriela Eguía-Lis en los apéndices a la edición facsimilar de los tres tomos originales ${ }^{32}$, sólida base para una futura edición crítica. Creo haber hecho un cotejo bastante completo entre las Eds. y la edición de MP, Obras completas, tomos 1, 2 y 3 , excluyendo el tomo 4, editado por Alberto G. Salceda, donde hay textos tan importantes como las dos comedias, el Neptuno alegórico, la Crisis sobre un sermón y la Respuesta a sor Filotea ${ }^{33}$, pues mi propósito ha sido limitarme a la labor de MP.

32 De hecho, no he utilizado sino los dos primeros, IC y $S V$. El tercero, Fama y Obras pósthumas, ofrece textos mucho más uniformes en sus cinco ediciones conocidas (1700-1725), o sea que no abundan allí las "variantes".

33 A semejanza de MP, que toma como base, cada vez que puede, el texto de cosas que se imprimieron en México antes que en España, también Salceda se basa en la edición mexicana del Neptuno (1680) y en la poblana de la Crisis (1690). Pero es evidente que sor Juana retocó y corrigió estas dos obras antes de remitirlas respectivamente a Madrid y a Sevilla. En el Neptuno no hay grandes divergencias (aunque Salceda ha tenido que acudir a las 
Por otra parte, Gabriela Eguía-Lis no utilizó todas las reediciones antiguas. Para la $I C$, falta un cotejo entre las dos ediciones de 1709; y para el $S V$, un cotejo entre las tres ediciones de 1693, y también la consulta de la edición de 1725. Me parece, sin embargo, muy dudoso que de esto resulte algo interesante.

En cambio, la utilización del pequeño cartapacio sorjuanino de la biblioteca de Antonio Rodríguez Moñino ${ }^{34}$ sí que aportará buenas novedades. El caso de este manuscrito se parece mucho al del llamado "manuscrito Lastanosa-Gayangos" (B.N.M., ms. 17.969), que contiene parte de las poesías de Garcilaso. También el ms. Moñino contiene algunas poesías de sor Juana. En los dos casos se trata de manuscritos únicos (en contraste, sobre todo, con los innumerables que contienen cosas de Góngora). Los dos manuscritos son obra de copistas sumamente torpes, pero los dos presentan a veces (jdonde menos se espera salta la libre!) variantes dignísimas de atención. He aqui un buen ejemplo en cuanto a Garcilaso: en todas las ediciones antiguas y modernas, se lee (Égloga III, 105-112) que las telas dt las ninfas están hechas y tejidas "del oro que el felice Tajo en vía” entre sus arenas, "y de las verdes hojas, reducidas / en es tambre sotil". Pero el ms. Lastanosa-Gayangos no dice hojas sino ovas. ¡Tal es, obviamente, la lección buena! Las ninfas fa brican sus telas con lo que tienen a mano: las algas del fond del Tajo y el oro de sus arenas ${ }^{35}$. Con el ms. Moñino sucede 1 . mismo. He aquí, por ejemplo, una cuarteta del romance de lo celos (3:125-128) (pongo a la izquierda el texto de las Eds. y d MP, y a la derecha el del ms. Moñino):

Eds. para corregir varias erratas de la edición mexicana). Pero en la Crisis las hay, y en abundancia. Baste un ejemplo. En la edición poblana se le "morir fue la mayor fineza en la graduación del mismo Cristo, siendo su M jestad quien únicamente las sabe graduar. Por eso al expirar Cristo dic Consummatum est" (ed. Salceda, líneas 203-205). En cambio, en el SV se le “...en la graduación del mismo Cristo, que es quien únicamente sabe g1 duar sus finezas. Y aun por eso dice al expirar...", etc. Las frases son aquí $\mathrm{m}$ fluidas, y los cambios no pueden deberse sino a la autora. En una edici crítica, el texto base debiera ser el de la versión definitiva, o sea el del $S V$.

${ }^{34}$ Estudiado por William C. Bryant en $A L M, 4$ (1964), 277-285. (Mo1 no se lo compró a un librero-anticuario portugués.)

35 Elias L. Rivers registra la lección ovas en su edición de Obras completas 1964; en la de 1969 (Clásicos Castalia), donde no hay aparato crítico, imprir hojas, con una nota aclaratoria para el estudiante universitario: "Se refiere a seda, producida cuando los gusanos convierten en hilo las hajas del mor: (Lo cual es suponer un criadero de gusanos de seda en el fondo del Tajo.) 
Para tener celos basta sólo el temor de tenerlos; que ya está sintiendo el daño quien está sintiendo el riesgo.
Para tener celos basta sólo el temor de tenerlos; que ya está sintiendo el daño quien está temiendo el riesgo.

Es claro que el impresor de la $I C$ repitió mecánicamente el sintiendo, y que en el ms. Moñino se salva la lección original. (Lo cual nos hace ver con qué facilidad irrumpen las erratas.) Lo mismo vale para un pasaje de la respuesta al caballero del Perú (48:17 ss.). Dice sor Juana que Apolo, las Musas y el Pegaso se quedan alelados al oír los versos de ese caballero; que, "contra todo el orden" establecido, dejan en suspenso

$$
\begin{array}{ll}
\begin{array}{ll}
\text {.. los gorjeos Helicona, } \\
\text { los murmurios Aganipe; } \\
\text { porque, sus murmurios viendo, }
\end{array} & \begin{array}{l}
\text { los murmurios Aganipe; } \\
\text { porque, sus numeros viendo, } \\
\text { todas las Musas coligen }
\end{array} \\
\begin{array}{l}
\text { todas las Musas coligen } \\
\text { merecen ser aprendices. }
\end{array} & \begin{array}{l}
\text { que de vuestros versos no } \\
\text { merecen ser aprendices. }
\end{array}
\end{array}
$$

También aquí la repetición de murmurios es una obvia errata, y la lectura correcta es números (la armonía y sonoridad de los versos).

Más aún: en el romance al Dr. Vega y Vique (núm. 38) el impresor de la $I C$ se saltó toda una cuarteta (entre los vv. 196 y 197). Vega y Vique ha puesto por las nubes un "pobre romance" de sor Juana. Si mis versos - dice ella-fueran obra de poetisas antiguas como Safo, Erina, etc., o de poetisas modernas como la excelsa duquesa de Aveiro, entonces sí estarían justificados los elogios. Pero en el ms. Moñino, a continuación del elogio a los versos de la duquesa, hay esto:

...y de otras muchas, con quien

la Naturaleza quiso borrar el vulgar oprobio del género femenino.

Esta apología del valor intelectual de la mujer es uno de los "caballitos de batalla" de sor Juana. Yo no vacilaría en reponerlos en su sitio ${ }^{36}$.

\footnotetext{
${ }^{36} \mathrm{He}$ aquí otras variantes de interés: "Pero ¿quién tan atacado / les podrá poner el freno...?" (ms. Moñino) > "Pero ¿quién con tal medida...?"
} 
Las erratas que se cuelan en los impresos suelen ser muy insidiosas y muy tenaces. Un ejemplo claro es el del soneto "Dichoso aquel que en un comprado prado...", como se lee en todas las ediciones de los Pastores de Belén de Lope de Vega, y que obviamente tiene que ser "en no comprado prado", pues una de las grandes bienaventuranzas de los inocentes labriegos es que las tierras que cultivan les vienen por herencia, no por una operación de compraventa (Horacio, Beatus ille, v. 3: "paterna rura bobus exercet suis"; Marcial, epigrama "Vitam quae faciunt beatiorem", v. 3: "res non parta labore, sed relicta"). Enorme mérito de MP es haber descubierto no pocos gazapos de esta índole. Pero creo que la depuración del texto puede lievarse un poco más allá en los casos siguientes:

Un "caballero recién venido a la Nueva España" se acusa an te sor Juana de haber caído en la herejía de negar la existenci: del Fénix, y que "las Musas, como soplonas", lo acusaron ant Apolo; Apolo, sumamente indignado, le hace saber entonces en un mensaje traído por Mercurio, que le queda prohibida l: subida al Parnaso si persiste en tamaño error, "y que jura, por $\mathbf{l}$ Estigia, / que no ha de desenojarse / si al ave que está de none / pares no le pido a pares". Algo anda mal, desde luego. MP in prime "paces no le pido a pares" ( 48 bis, v. 32), pero comenta es nota: "pudiera ser lapsus por parces, plural del substantivado in perativo latino parce, o sea “iperdóname!'”. Yo creo que ésta $\epsilon$ la solución que se impone, y no la otra ${ }^{37}$. Un contrito Parce mih está a tono con el lenguaje llano y jovial del gracioso romanc (que mereció una no menos graciosa respuesta de sor Juana).

(3:157): aquí sor Juana parece haber querido "elevar" la expresión y sacri có el tan atacado, que yo hubiera preferido. || En el romance al Dr. Vega y que le dice sor Juana que de su colosal elogio se podrá decir lo que ‘ Egipto, "que una pirámide tal / erigió para un mosquito. / Pero hételo Gr vara..." (ms. Moñino) > "erigió para un mosquito, / y... mas hételo Guer ra" (38:213): aquí las Eds. muestran un retoque mínimo, pero muy certer con el " $y$..." da a entender sor Juana que iba a seguir acumulando compa ciones, pero que en ese momento le avisaron que ya estaba Guevara en el cutorio, y tuvo que renunciar a ellas.

37 En la misma nota dice MP que "pares no le pido" es errata de la e ción de 1725, y da a entender que él sigue la lección del SV: "paces no le do". Pero esto es inexacto: todas las Eds. dicen "pares no le pido". - Un pc antes (v. 24) se lee en el $S V$ que Apolo "despacha con un mensaje / al cor dor de los dioses, / volador, y aun triquitraque”, o sea, más rápido quizá c un volador ('cohete'): un verdadero triquitraque (un petardo). MP cam "y aun triquitraque" por "y un triquitraque", lo cual destruye el chiste. 
En el romance a Diego Valverde se lee: “...quedaremos / yo sin la deuda, gustoso / vos, y todos contentos". A este último verso le falta una sílaba. MP imprime "vos, y todos muy contentos" (39:144), pero propongo como mejor la castiza expresión "y todos tan contentos", que va muy bien con el tono coloquial del romance.

Otro verso cojo en las Eds. es el 320 de El cetro de José: "Calla, no prosigas". La solución de MP: "Calla, no ya prosigas", es muy desafortunada; seguramente quiso remediar con esta cacofonía otra cacofonía: "Calla, ya no prosigas". Pero ¿no sería mejor "Cállate, no prosigas"?

Cojo es también el v. 289 de El mártir del Sacramento: "o a qué fin nos lo acuerdas". MP imprime "y con qué fin nos lo acuerdas". Creo que sería mucho mejor "o a qué fin nos los recuerdas".

En la loa núm. 374, vv. 354 ss., el Cielo, refiriéndose al Rey, dice que América "al parabién de sus dichas / alega:justos derechos", y prosigue: "Gócela en vos, pues en vos / solo logran sus desvelos". MP corrige "Gócelas en vos: que en vos" (las: las dichas). Pero yo creo que el error está más bien en el plural "sus dichas" (debido a que en el verso anterior hay "los ecos" y en el siguiente los "derechos"). De ese modo el "Gócela" está bien, y no hay necesidad de sustituir pues por que.

En el v. 315 de esa misma loa le dice el Cielo al arzobispo-virrey que "los dos distantes gobiernos" están en deuda con él. Así se lee en la $I C$; en la edición de 1691 se comieron el dos: "los distantes gobiernos"; en 1709, para remediar la cojera del verso, imprimieron "los más distantes gobiernos", que es la lección que MP adopta. Pero es claro que la corrección de 1709 se hizo a la buena de Dios. Hay que regresar a la $I C$, pero haciendo en "los dos distantes gobiernos" una pequeña corrección: "los dos distintos gobiernos" (el "eclesiástico" y el "político", como dice sor Juana) cuyas riendas empuña fray Payo Enríquez de Ribera.

En el romance "Yo, menor de las ahijadas", los vv. 133 ss. dicen en la $I C$ : "la esmeralda... / se roba la luz al cielo / y al campo usurpa los visos". En la reedición de 1690 corrigieron: "se roba la luz del cielo" (y así dice también MP). Pero creo que es mejor otra solución: "le roba": la esmeralda le roba al cielo su luminosidad y al campo su color. (Como errata de imprenta, es más explicable $l e>$ se que $a l>d e l$.)

En su enhorabuena a la virreina por el bautizo de su hijo le dice sor Juana: "tú le quieres / llamar hijo de la Iglesia" y, ahora que ha amanecido a la luz de la Gracia, "no estimes / la de la 
Naturaleza". Así la IC: MP remedia la discordancia modal entre quieres y estimes y pone los dos verbos en indicativo (24:11 y 15). Si se atiende al hilo del discurso, major es lo contrario: "Crédito es de tu piedad / que [lo quieras] hijo de la Iglesia" y no estimes ya la ley natural.

En una de las loas interviene a trechos la Música cantando seguidillas, una de las cuales dice así en la $I C$ : "que si compuesto / es alma y cuerpo, / no puede quedar hombre / sin el compuesto", con un primer verso cajo, enmendado por MP con cirugía mayor: "que si el compuesto humano..." (375:205). Más simple sería: "que si bien el compuesto..."

El v. 3 del soneto núm. 182 dice en las Eds. (y en MP): "alguno que tus prendas conociera"; pero tiene que ser alguna, como se ve por el v. 9: "aquella que te hubiere conocido". El soneto es respuesta galante (femenina) a un soneto galante (masculino) .

Al hijo de los virreyes, cuando cumple un año, le dice sor Juana (25:79): "Ya habéis visto doce signos [los zodiacales] / ) en todos, Alcides nuevo, / venciendo doce trabajos" (sic Eds y MP). Creo que es necesario corregir: "Ya habéis visto doce sig nos y vencido doce trabajos".

"Cuando otros lloren tormentos, / entonarán mis bonanzas / Nadie de mí se duela..." (16:43). Pienso que tormentos es erra ta por tormentas, antítesis de bonanzas.

En el Sueño describe sor Juana el leve ropaje que la rosa "ex plica" (despliega) al viento, ropaje "que en una y otra frese: multiplica / hija, formando pompa escarolada" (v. 740). La Eds. y MP repiten lo que para mí es una "clásica" errata de in prenta: hija en vez de hoja. Ni la rosa ni su ropaje tienen hija: se trata de las hojas. Desplegar un ropaje multiplicado "en un y otra hoja" es lucirlo pétalo a pétalo.

Antonio Alatork

El Colegio de Méxic

\footnotetext{
38 De hecho, en la $I C$ se lee "ser alma y cuerpo", pero la fe de erratas c dena: "léase es". En otra de las seguidillas corrige MP "que si en Carlos " mos" > "que si vemos en Carlos", corrección inútil, pues las seguidil admiten hexasílabos ocasionales en vez de heptasílabos.
} 